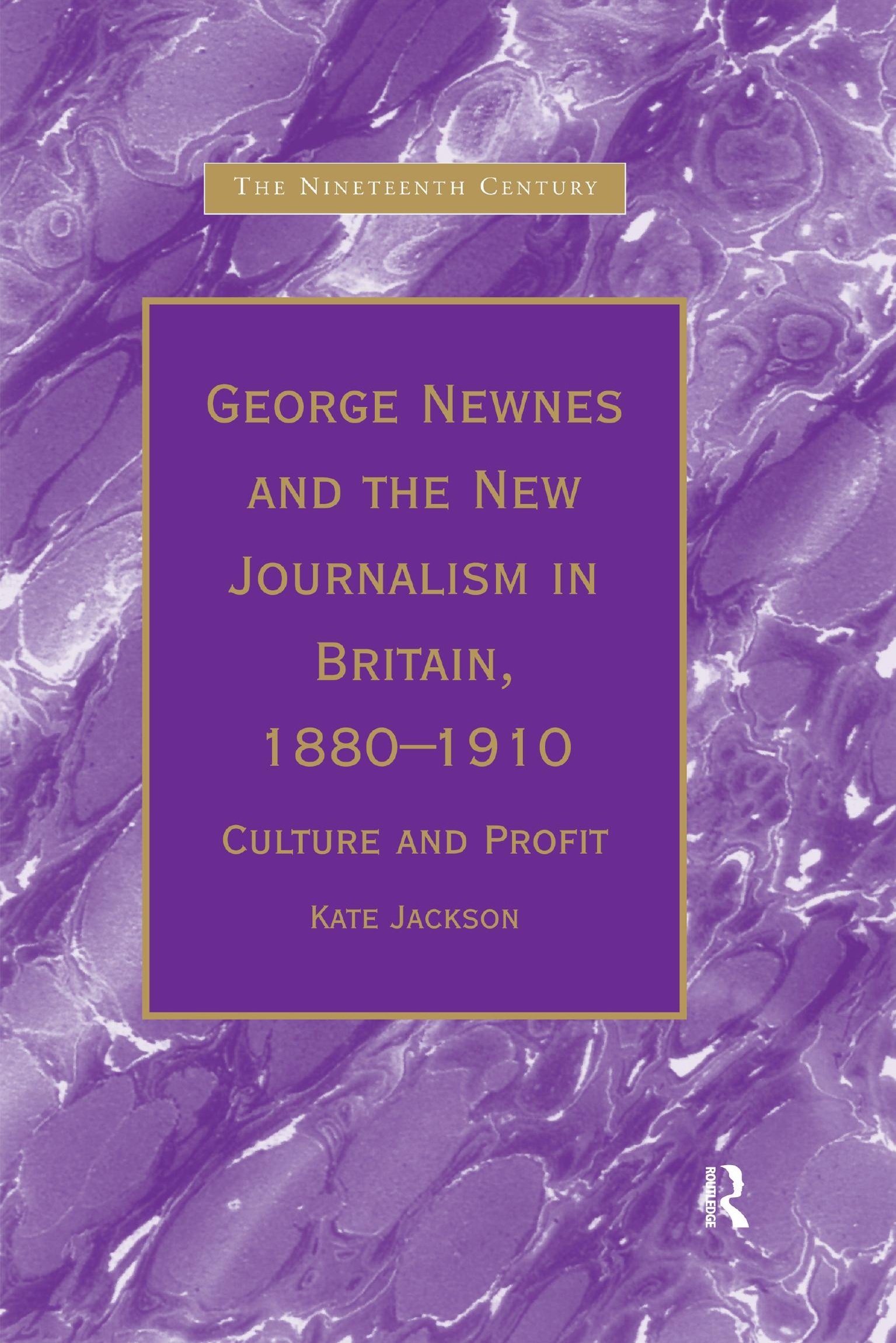


George Newnes and the New Journalism in Britain, 1880-1910 


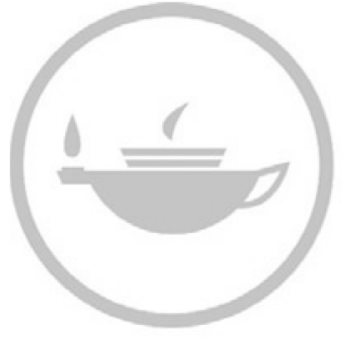

Taylor \& Francis
Taylor \& Francis Group http://taylorandfrancis.com 


\section{George Newnes and the New Journalism in Britain, 1880-1910}

\section{Culture and Profit}

Kate Jackson

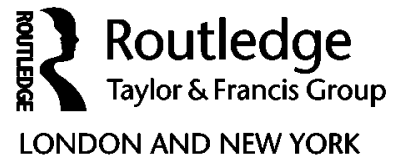


First published 2001 by Ashgate Publishing

Published 2016 by Routledge

2 Park Square, Milton Park, Abingdon, Oxon OX14 4RN

711 Third Avenue, New York, NY 10017, USA

Routledge is an imprint of the Taylor \& Francis Group, an informa business

Copyright (C) Kate Jackson, 2001

Kate Jackson has asserted her moral right under the Copyright, Designs and Patents Act, 1988, to be identified as the author of this work.

All rights reserved. No part of this book may be reprinted or reproduced or utilised in any form or by any electronic, mechanical, or other means, now known or hereafter invented, including photocopying and recording, or in any information storage or retrieval system, without permission in writing from the publishers.

Notice:

Product or corporate names may be trademarks or registered trademarks, and are used only for identification and explanation without intent to infringe.

British Library Cataloguing in Publication Data

Jackson, Kate

George Newnes and the New Journalism in Britain, 1880-1910: Culture and Profit - (The Nineteenth Century Series)

1. Newnes, George. 2. Journalism-Great Britain-History-19th century. 3. Journalism-Social aspects-Great Britain. I. Title.

$072^{\prime} .09034$

US Library of Congress Control Number

The Library of Congress Control Number was preassigned as: $00-108812$

ISBN 13: 978-0-7546-0317-7 (hbk)

\section{Publisher's Note}

The publisher has gone to great lengths to ensure the quality of this book but points out that some imperfections from the original may be apparent. 


\section{Contents}

Figures

vii

The Nineteenth Century General Editors' Preface ix

Acknowledgements

Introduction

Part I The New Journalism: A Liberal Profession or a Branch of Business?

Introduction to Part I

1 Securing the Suffrage of the Crowd: Tit-Bitites and Millionaires: Tit-Bits (1881) and The Million (1892)

2 A National Institution: The Strand Magazine (1891)

Part II Liberalism and Imperialism: Developing Formats and Expanding Horizons

Introduction to Part II

3 A Bold Stroke of Mingled Business and Benevolence:

The Westminster Gazette (1893)

4 Expanding Human Consciousness Across the Globe:

The Wide World Magazine (1898)

Part III Specialisation and Diversification: Targeting Niche Audiences and Exploiting a Segmented Market

Introduction to Part III 
5 Femininity, Consumption, Class and Culture in the Ladies' Paper: The Ladies' Field (1898)

6 Respectable Anxieties, Role-Models and Readers:

The Captain (1899)

Conclusion

George Newnes: Biographical Summary

Select Bibliography

Index 


\section{Figures}

1 Bust of Newnes at Putney Library 36

2 Opening of Lynton Town Hall, 1900 36

3 Triumphal arch above the entrance road to Hollerday House, $1898 \quad 37$

$4 \quad$ George Newnes, by Spy $\quad 37$

5 'A Few Incidents in Connection With Tit-Bits' 86

6 Publicity photograph of 'Tit-Bits Villa', 1884

$7 \quad$ Cover of The Strand 118

8 Illustration accompanying The Strand's two hundredth number 118

9 Political cartoon by F.C. Gould in The Westminster Gazette, $1900 \quad 162$

10 'A Nightmare Bunker', by F.C. Gould in The Westminster Gazette, $1905 \quad 162$

11 Cover of the bound volume of The Wide World Magazine 195

12 'Odds and Ends' from The Wide World Magazine, $1900 \quad 196$

13 Wide World contents-map 196

14 'A Halt for Breakfast in West Africa' from The Wide World

15 'A Solomon Islander Imitating a Missionary in the Hope of Acquiring his Virtues', from The Wide World MagazineI, 1899197

16 'How I Shot My First Elephant' from The Wide World Magazine, $1910 \quad 198$

17 The Ladies' Field header illustrations 235

18 'The Old Fag' editorial header 261

19 Pictures of C.B. Fry in The Captain 261 


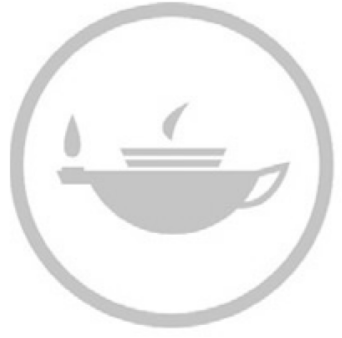

Taylor \& Francis
Taylor \& Francis Group http://taylorandfrancis.com 


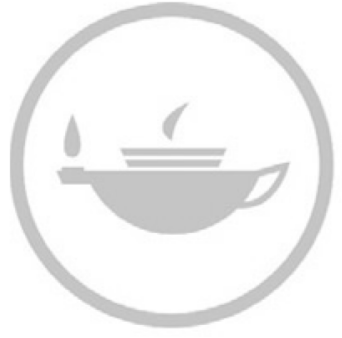

Taylor \& Francis
Taylor \& Francis Group http://taylorandfrancis.com 


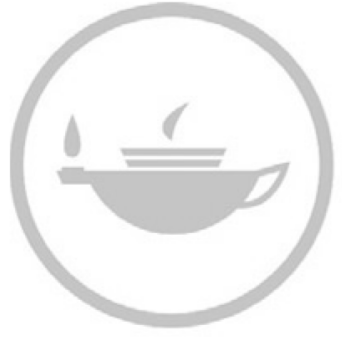

Taylor \& Francis
Taylor \& Francis Group http://taylorandfrancis.com 


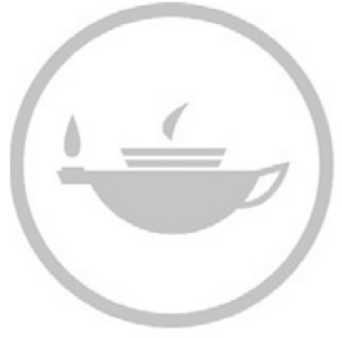

Taylor \& Francis
Taylor \& Francis Group http://taylorandfrancis.com 


\section{Introduction}

George Newnes was one of the most influential British publishers of the late Victorian and Edwardian periods. He established a vast number and variety of journals in the years from 1881 until his death in 1910, personally editing some of these, shaping the character and format of others, and leaving an impression upon all of them. By 1905, only Alfred Harmsworth was producing more newspapers and magazines than Newnes. The periodicals that George Newnes created included Tit-Bits (1881), The Strand Magazine (1891), The Million (1892), The Westminster Gazette (1893), The Wide World Magazine (1898), The Ladies' Field (1898) and The Captain (1899). This list covered a diverse range of journalistic prototypes: the penny weekly, the sixpenny illustrated magazine, the colour-printed paper, the penny evening newspaper, the true story magazine, the women's magazine and the boys' paper. It therefore represents an immensely rich archive of journalistic and cultural material. Many of these publications achieved and sustained substantial circulations. Through them, Newnes pioneered new styles, formats and journalistic techniques, and accessed new audiences. And he flavoured everything he published with his own views of people and the world they inhabited and were shaping. The personality and innovative flair of George Newnes thus pervaded British journalism for thirty years.

When asked to account for his own success in periodical publishing, Newnes replied:

Most people have no idea of doing anything beyond what they may have seen done before, and what they are told to do. They are frightened by originality, lest it might be disastrous. I suppose I have been inclined to do things differently from, rather than in the same way as, other people, and I have always struck while the iron was hot. That, I think, to put it briefly, is the secret of any success which has attended my efforts.'

1 Hulda Friederichs, The Life of Sir George Newnes, Bart, London: Hodder and Stoughton, 1911, p. 144. 
The ingredients of Newnes's success as an entrepreneurial publisher and the rules of his engagement with his readers were, as he saw them, originality and timing.

Alfred Harmsworth said of Newnes, in the obituary be wrote for The Times in 1910:

Most of [his] earlier publications were new ideas hitherto untried in English journalism, and their distinguishing mark was a striking and unusual success. Mr Newnes had found a market which had been created by the spread of popular education, and he proceeded to extend still further the operations of his publishing house.

Harmsworth was one of the first to place Newnes as a key figure of the so-called New Journalism that ushered in the modern age. Since then, a succession of twentieth-century journalists, historians and critics has invoked the name of George Newnes as one of the creators of modern journalistic practice. ${ }^{3}$ Not everything Newnes produced was 'new', and the way in which Newnes's publications represented a marriage of new and old practices will be a major theme of this book. Nor were his journals entirely unique. Yet according to Joel Wiener, he was one of a number of leading New Journalists whose innovations were critical to the formation of the modern popular press:

These men experimented with new techniques and drew on American examples at a time when a considerable expansion of the press was taking place. They were innovators in a new type of journalism and deserve to be remembered as such. ${ }^{4}$

Despite this recognition, there has been no systematic study of the diverse range of Newnes's periodical publishing career. There remains only one biography of Newnes, written by his friend and colleague Hulda Friederichs in the year after his death. ${ }^{5}$ Friederichs made use of Newnes's own autobiographical jottings, written in preparation for an autobiographical work which was never completed. This has been supplemented by various references

2 The Times, 10 May, 1910.

3 See for instance, Harold Herd, The Making of Modern Journalism, London: Allen and Unwin, 1927; T.H.S. Escott, Masters of English Journalism, London: T. Fisher Unwin, 1911; Hulda Friederichs, op. cit.; E.T. Raymond, Portraits of the Nineties, London: T. Fisher Unwin, 1921; Brian Braithwaite, Women's Magazines: The First 300 Years, London: Peter Owen, 1995.

4 Joel Wiener, 'How New was the New Journalism?', in Joel H. Wiener (ed.), Papers for the Millions: The New Journalism in Britain, 1850s-1914, New York: Greenwood Press, 1988, pp.58-59.

5 Hulda Friederichs, op. cit. Friederichs was German by birth, and possessed a knowledge of many languages. She became acquainted with W.T. Stead upon her arrival in England, and obtained a post on the Pall Mall Gazette, then edited by Stead. She subsequently wrote for Newnes's Westminster Gazette, and edited its sister publication The Westminster Budget for many years. 
to Newnes and his publishing activities in biographies of other editors, publishers, proprietors and journalists and in general histories of journalism, and by the chapter on Newnes in John Travis's recent local history of Lynton and Lynmouth, twin towns in North Devon in which he is still remembered as the towns' biggest benefactor. ${ }^{6}$

The publications of the House of Newnes have attracted some attention in the historiography of the late nineteenth and early twentieth-century periodical press. Tit-Bits has been noted for its novelty, circulation and influence on successive journalistic enterprise. Its character and circulation have placed Newnes at the centre of a long-running debate on the expansion of the popular press in the late nineteenth and early twentieth centuries. The Million, on the other hand, has received virtually no mention. The Strand Magazine has assumed some importance in the historiography of periodical literature because of its literary reputation, built upon the status of its contributors, and the popularity that it sustained for more than half a century. It has been examined by Reginald Pound, in Mirror of the Century: The Strand Magazine, 1891-1950. Pound was a later editor of The Strand. His book, part history and part autobiography, contains a wealth of invaluable material now unavailable: archival evidence relating to the House of Newnes as well as The Strand itself (such as share prices, annual profits and the sums paid to authors for their various contributions), and anecdotal evidence gleaned from many contemporary journalists and from members of Newnes's family. ${ }^{7}$ The Strand has also been selectively indexed by Geraldine Beare. ${ }^{8}$ The Wide World Magazine has been cited as a 'story magazine' and noted for its publication of the controversial story of Louis de Rougemont in the 1890s. ${ }^{9}$ The Westminster Gazette has been examined, though far from exhaustively, in the light of its political connections and influence, and as the organ of its well-known editor, J.A. Spender. The Captain has been acknowledged as one of the most successful juvenile periodicals of the early twentieth century, but has remained unresearched. However, none of these publications have been incorporated into a comprehensive and interdisciplinary study of the periodical publishing activities of George Newnes.

6 See Reginald Pound and Geoffery Harmsworth, Northcliffe, London: Cassell, 1959; T.H.S. Escott, op. cit.; Harold Herd, The March of Journalism: The Story of the British Press from 1622 to the Present Day, London: Allen and Unwin, 1952; Alan J. Lee, The Origins of the Popular Press, London: Croom Helm, 1976; Stephen Koss, The Rise and Fall of the Political Press in Britain, Chapel Hill: University of North Carolina Press, 1984, vol. 2; John Travis, An Illustrated History of Lynton and Lynmouth, 1770-1914, Derby: Breedon Books, 1995.

7 Reginald Pound, Mirror of the Century: The Strand Magazine, 1891-1950, London: Heinemann, 1966.

8 Geraldine Beare (comp.), Index to the Strand Magazine, 1891-1950, Westport, Connecticut and London: Greenwood Press, 1982.

9 Q.D. Leavis, Fiction and the Reading Public, London: Chatto and Windus, 1932, p.11. 
This book aims to elucidate the significance of George Newnes to British journalism and culture in the late Victorian and Edwardian periods. The figure of Newnes is its binding thread. It evaluates a collection of seven periodicals which differ in frequency of publication, audience, appearance and appeal. Tit-Bits, for example, was a penny weekly largely aimed at a lower middle-class readership; The Strand a sixpenny illustrated monthly with an essentially upper middle-class circulation; The Westminster Gazette a penny Liberal evening paper with a small but dedicated readership; and The Ladies' Field and The Captain both specifically-targeted and well-produced illustrated magazines. ${ }^{10}$ These publications were linked, however, by the involvement of Newnes in their creation and production, his influence manifested in a multitude of ways. Many of them have received little historiographical attention or, if they have been examined, can be further illuminated through a methodology which locates them within a range of Newnes periodicals with linking features, and analyses them through a combination of various critical, historiographical and methodological perspectives available to the contemporary historian.

\section{Historiography}

The historiography of periodical literature has included a range of studies of individual periodicals or of a limited period in the life of a magazine; celebratory studies of various journals, commissioned to mark publication anniversaries; and biographies of founders or notable editors. ${ }^{11}$ Monographs have generally been limited to magazines deemed particularly influential in their age and belonging to a particular, generally middle and upper class, cultural ethos (although the influence of 'cultural populism' has led to a number of more recent studies examining 'popular' publications). Most scholars, as Brian Maidment has pointed out, have 'come at periodicals obliquely' through an interest in an individual who contributed to periodicals, in an event or issue that was described in periodicals, or in pictures, books and performances reviewed in periodicals. Many articles, books and essays have employed evidence drawn from periodicals for illustrative or substantiative purposes. ${ }^{12}$ Histories of publishing houses have tended to rely heavily on manuscript sources, and have often been biographical in

${ }^{10}$ C.B. Fry's Magazine was another of Newnes's most successful specifically-targeted magazines. It was a monthly illustrated sporting journal, established by Newnes in 1904, and edited by the famous sportsman C.B. Fry. This magazine is not discussed extensively here for reasons of space, but is the subject of a number of articles by the author of this book.

11 J. Don Vann and Rosemary T. Van Arsdel (eds), Victorian Periodicals: A Guide to Research, New York: Modern Language Association, 1978, p. 105.

12 Brian Maidment, 'Victorian Periodicals in Academic Discourse' in Laurel Brake, Aled Jones and Lionel Madden (eds), Investigating Victorian Journalism, New York: St Martin's Press, 1990 , p.144. 
orientation, and descriptive in style rather than thematic, conceptual or theoretical. ${ }^{13}$

Since the $1960 \mathrm{~s}$, a number of research societies and journals have been established, all of them attempting to open up the vast uncharted territory of research into newspapers, periodicals and the history of publishing. ${ }^{14}$ The pioneering work encouraged by the Research Society for Victorian Periodicals in the 1960 s tended to take the form of archival research, and included indexes and bibliographic research guides such as The Wellesley Index, The Waterloo Directory, Victorian Periodicals: A Guide to Research and Victorian Periodical Press: Samplings and Soundings. It also included surveys of the nineteenthcentury press, and many articles and books describing the careers of individual editors, authors, and periodicals. ${ }^{15}$ The history of print culture has burgeoned in the last ten years, and national 'histories of the book' (as they are known to scholars in the field) have proliferated. ${ }^{16}$ Such studies, examining issues of production, distribution, formal character and reception, represent the intersection of economic, literary and social history. Whilst various recent research initiatives have sought to address the problem of locating, indexing and recording the archives of British and American publishers and related groups such as Publishers' and Writers' Associations, none have sourced material relating to George Newnes, $\mathrm{Ltd}^{.17}$ This is a reflection of the fact that such material is scarce,

13 See, for instance, Charles Morgan, The House of Macmillan, London: Macmillan, 1943; Patricia Thomas Srebrnik, Alexander Strahan: Victorian Publisher, Ann Arbor, Michigan: University of Michigan Press, 1986; F.A. Mumby, The House of Routledge, 18341934, London: Routledge, 1934; Lconard Huxley, The House of Smith Elder, London, 1923.

14 The Research Society for Victorian Periodicals was established in 1968, and began producing the Victorian Periodicals Newsletter, which later became the Victorian Periodicals Review. The Journal of Publishing History was established in 1977, and the Journal of Newspaper and Periodical History in 1984. The Society for the History of Authorship, Readership and Publishing began bringing out its quarterly newsletter (SHARP News) in 1992, and launched its annual journal, Book History, in 1997.

15 Walter E. Houghton (ed.), The Wellesley Index to Victorian Periodicals, 1824-1900, Toronto: University of Toronto Press, 1966; The Waterloo Directory of Victorian Periodicals, 1824-1900, Waterloo, Ontario, 1976; J. Don Vann and Rosemary T. Van Arsdel (eds), op. cit.; Joanne Shattock and Michael Wolff (eds), The Victorian Periodical Press: Samplings and Soundings, Leicester: Leicester University Press, 1982. See also Alan J. Lee, op. cit.; Lucy Brown, Victorian News and Newspapers, New York: Oxford University Press, 1985.

16 A collaborative project on the History of the Book in Australia (HOBA), for instance, was begun in 1996.

17 Chadwick-Healey are engaged in producing vast collections of microfilm reels including Richard Bentley and Son, 1829-1898; George Allen, 1893-1915; Macmillan, 18541924; and George Routledge, 1853-1902. Simon Fraser University began the 'Publisher's Papers Project' in 1994, developing a database that locates Canadian publishing company records in both public institutions and the offices of Canadian publishers, personal papers of individuals involved in publishing, and the papers of related groups. The author made a number of visits to IPC Magazines, into which George Newnes, Ltd was incorporated in 1958, in an effort to obtain such material. It appeared that the bulk of the records of the company had been placed in storage in a disused underground tunnel during the Second World War, and that it was now impossible to locate or view them. 
a fact which has influenced the nature of this book inasmuch as its focus is on textual rather than archival sources.

The period under scrutiny was one of the most dynamic periods in British journalism and culture. Many argued that it saw the invention of a new journalism which was to diversify the field of periodical publishing and shape all subsequent journalistic development. The historiography of New Journalism has included a number of essay collections which have proved useful for this study, such as Newspaper History from the Seventeenth Century to the Present Day (edited by Boyce, Curran and Wingate), Papers for the Millions (Joel Wiener) and Investigating Victorian Journalism (Brake, Jones and Madden). Many scholars have made useful contributions to the debate over the novelty of the New Journalism. Francis Williams has asserted that New Journalism was responsible for, amongst other things, the dichotomy in the British press between 'quality' and 'popular' newspapers. Examining typographic trends in newspapers from 1622, both Stanley Morrison and Allen Hutt have shown that the innovations of New Journalism helped to create a lively press. Cynthia White, Margaret Beetham and Brian Braithwaite have all discussed the emergence of mass periodicals for women. ${ }^{18}$ Personality, both editorial and within the proliferating 'human interest' stories, was a prominent feature of the New Journalism, and innovative editors such as W.T. Stead and T.P. O'Connor marketed themselves strenuously to the public. There have been many studies of both of these men. Joseph Baylen, for instance, has argued that the New Journalism was defined primarily by Stead, who employed popular methods of journalism to achieve moral goals. ${ }^{19}$ Despite the existence of various volumes of memoirs, biography and autobiography, there has been relatively little treatment of other leading New Journalists. And of the leading press magnates only Northcliffe (Alfred Harmsworth) has attracted significant attention.20

18 Francis Williams, Dangerous Estate: The Anatomy of Newspapers, London: Longman, Green, 1957; Stanley Morrison, The English Newspaper: Some Account of the Physical Development of Journals Printed in London Between 1622 and the Present Day, Cambridge: Cambridge University Press, 1932; Allen Hutt, The Changing Newspaper: Typographic Trends in Britain and America, 1622-1972, London: Gordon Fraser, 1973; Cynthia White, Women's Magazines, 1693-1968, London: Michael Joseph, 1970; Margaret Beetham, A Magazine of Her Own? Domesticity and Desire in the Woman's Magazine, 18001914, London and New York: Routledge, 1996; Brian Braithwaite, op. cit.

19 Joseph O. Baylen, "The "New Journalism" in Late-Victorian Britain', Australian Journal of Politics and History, 18 (1972), pp.367-385. See also Joseph O. Baylen, 'W.T. Stead and the New Journalism', Emory University Quarterly, XXI (1965), pp.196-206; 'The Press and Public Opinion: W.T. Stead and the "New Journalism", Journalism Studies Review, 4 (July 1979), pp.45-49; Frederic Whyte, The Life of W.T. Stead, 2 vols, London: Jonathan Cape, 1925.

20 See, for example, Reginald Pound and Geoffrey Harmsworth, op. cit.; Paul Ferris, The House of Northcliffe: The Harmsworths of Fleet St, London: Weidenfeld and Nicolson, 1971; R.D. Blumenfeld, The Press in My Time, London: Rich and Cowan, 1933 and R.O.B.'s Diary, 1887-1914, London: William Heinemann, 1930; Sidney Dark, The Life of Sir Arthur Pearson, Bt, G.B.E., London: Hodder and Stoughton, 1922; Henry Lucy, Sixty Years in the Wilderness, London: Smith, Elder, 1909 and The Diary of a Journalist, 3 vols, London: John Murray, 1923. 
In one respect, this study is a contribution to the debates surrounding New Journalism and the history of the popular periodical press. It will explore the nature of authorship as it relates to Newnes's periodicals, covering such issues as editorial voice and the authority structure of the late nineteenth-century periodical press. It will examine the evolution of new formats, focussing on the significance of advertising, and the emergence of popular and innovative features such as the interview, the character sketch, the competition, the portrait series and the correspondence column. And it will interrogate the character of journalistic developments and techniques of the period: the distinctions and continuities between the old journalism and the new, serious journalism and commercial journalism, and the popular and quality presses; the use of commercial and promotional schemes; the development of new technologies of colour and photographic reproduction; the development of different types of journals such as the penny weekly and the true story magazine; and the development of journalistic specialisation and market segmentation (the journalistic version of 'divide and conquer'). Illustrations from both textual and other sources have been included at the end of the chapters to which they refer. The photographic prints relating to this Introduction underline the connection between Newnes's public image and the persona he developed as a periodical editor and proprietor. In other sections, magazine covers, pictorial headers and illustrations have been selected to evoke the material appearance of the various publications and impress upon the reader the importance of the periodical's visual impact. The captions which accompany the illustrations locate, describe, and, in some cases, briefly comment upon the various visual features and techniques employed by Newnes. The analysis of the periodical publications of George Newnes will consist in the interweaving of arguments relating to production, distribution, reception and the nature of the periodical as a cultural text.

This is, in many ways, an interdisciplinary study, which crosses the boundaries between history, literary criticism, cultural and media studies and intellectual biography. The scholarship of these fields has both provided some of the methodologies which it utilises and suggested some of the themes which it explores. It attempts to answer, for instance, the challenge posed by recent work in cultural studies and literary criticism concerning the relationship between the industrial production of cultural forms and the consumption or reception of those forms, and offers a model of the periodical text (especially with respect to TitBits and The Million) which is a dialectical combination of creation and reflection; of production and reception; of openness and closure. The periodical, it is argued, is a culturally-embedded social object which is a product of negotiation and interaction between editor-proprietor and audience, and is as much context as text. The analysis of The Wide World Magazine is a clear example of the interweaving of text and context.

In the recent scholarship of periodical literature, empirical studies have been supplemented by and conjoined with a developing 'metacriticism' of 
periodical research, focussing on the methodology of periodical research. ${ }^{21}$ Scholars within media studies have debated whether the media sustains and reflects a consensual reality already in existence, or whether it produces or manufactures that consensus. Revisionist reception theorists have recently argued that production-centred studies have overstated the power of culture industries to exert ideological control over the meaning of their products. They have suggested that the audience of any cultural performance are social subjects who actively and variably engage with cultural texts on the basis of their lived experience. Reader-response critics contend that a text's 'effects' or results psychological or otherwise - are essential to an analysis of its meaning since the effective existence of any text is limited to its realisation in the mind of the reader. ${ }^{22}$ Their comments suggest a methodology within which the cultural text should be examined with reference to its place within a wider social, cultural and ideological formation.

It was this kind of approach that the founding texts of cultural studies Richard Hoggart's The Uses of Literacy, E.P. Thompson's The Making of the English Working Class, and Raymond Williams' Culture and Society and The Long Revolution - attempted to bring to the history of popular culture, in the late 1950 s and early 1960s. Hoggart, for instance, focussed on lived cultures and on the relation between texts and contexts. He demonstrated the kind of impulse towards the sociological reconstruction of British society that underpinned the Mass Observation project of the 1930s, when hundreds of Britons kept diaries of their daily lives for inclusion in a general sociological survey. ${ }^{23}$ Raymond Williams emphasised the communicative, creative nature of art and culture, arguing that 'communication is the crux of art, for any adequate description of experience must be more than simple transmission, it must also include reception and response'. When popular literature communicates, he concluded, 'a human experience is actively offered and actively received. Below this activity threshold there can be no art. 24 These scholars shared an interest in analysing the textual forms and documented practices of British culture. Where Matthew Arnold had associated popular culture with 'anarchy', and the Scrutiny school of critics with standardisation, 'levelling down' and cultural decline in general, these scholars found in popular culture a measure of positivity, stressing human agency and the

21 Laurel Brake and Anne Humpherys, 'Critical Theory and Periodical Research', Victorian Periodicals Review, XXII, 3 (Fall 1989), p.94.

22 They have employed such concepts as Walker Gibson's 'mock reader', and Gerald Prince's three classifications of 'narratee'. See Jane P. Tompkins (ed.), Reader Response Criticism: From Formalism to Post Structuralism, Baltimore and London: Johns Hopkins University Press, 1980. Reader-response critics also differ amongst themselves in the way in which they conceive the act of reading in relation to the creation of meaning.

23 See Richard Hoggart, The Uses of Literacy (Intro. Andrew Goodwin), New Brunswick: Transaction Publishers, 1992, p.xvi.

24 Raymond Williams, The Long Revolution, London: Penguin, 1961, pp.46, 42. 
active production and reception of popular culture. ${ }^{25}$ Some critics have attacked the consumptionist perspective of cultural populism, and pleaded for a return to Arnoldian certainties about culture: 'culture is the best that has been thought and said in the world'. Yet it is difficult to disagree with John Storey's response to this:

cultural populism's refusal to judge a text or practice 'good' or 'bad' is not in my opinion a crisis, but a welcome recognition that there are other, sometimes far more interesting, questions to be asked. ${ }^{26}$

Such historiographical debates have significantly influenced the methodology of this book: the questions to be asked. It aims to forge links between extensive empirical research on the outstanding examples of the periodical genre fashioned by George Newnes (after all, theoretical developments do not obviate the need for detailed and thorough empirical research), and more abstract theoretical notions about the nature of periodical literature. And it seeks to place Newnes's periodicals within a dynamic system of discursive and cultural interaction that included new technological developments, educational systems, social and political movements, oral cultural forms, tourist literature and imperialist propaganda, urban segregation and patterns of class formation, new patterns of leisure, changing notions of time and space, the evolution of a consumer culture, and the construction and dissemination of cultural stereotypes. This study will examine the manner in which Newnes's publications function historically as 'social discourse', and will assess the significance of his publications to the historiography of print culture, New Journalism and periodical research.

As a literary and popular form, periodical literature presents the historian with a particular set of methodological concerns revolving around the issue of the relationship between the text itself and the culture that produced it. One model for the interpretation of periodical literature has been the reflection model employed by Michael Wolff in his pioneering essay entitled 'Charting the Golden Stream'. Wolff suggested that 'The years that we call Victorian are best mirrored in the serial publications - literature, argument, the tastes and preoccupations of just about every level and sort of society, all display themselves in the newspapers and journals.' Walter Houghton adopted the reflection model in his introduction to the Wellesley Index in which he stated that periodicals were 'a remarkable record of contemporary thought' which 'reflect[ed] the current situation'. And John North described the periodical

25 In Culture and Anarchy (1869), the term 'anarchy' operates essentially as a synonym for popular culture, denoting Arnold's fear of the disruptive nature of a working-class lived culture and of political and social disorder. It is significant that he was writing amidst the suffrage agitation of $1866-1867$.

26 John Storey, An Introductory Guide to Cultural Theory and Popular Culture, New York: Harvester Wheatsheaf, 1993, p.183. 
press as a 'sensitive ... record of a civilisation'. ${ }^{27}$ This model obviously has a certain value. Yet it is problematic insofar as it implies that the media are secondary and derivative, existing above and beyond the 'real world' and passively mirroring society rather than forming an active and integral part of it. Victorian and Edwardian periodicals were, by their very nature (their appearance at regular intervals and dependence - financial and otherwise - upon reader response, and their varied composition) an extremely interactive and intertextual medium. This was something that Newnes understood and exploited very successfully.

Recent redefinitions of the methodological challenges of periodical research by structuralist, post-structuralist and a diverse collection of Marxist theorists within historiography, literary studies, and cultural and media studies have entailed a rethinking of the reflection model. Periodicals are no longer deemed mere reflective evidence through which to recover the culture that they mirror. They have come to be viewed as a central component of that culture; an 'active and integral part' of it to be understood only as part of that society and its discourses about the periodical press. ${ }^{28}$ Thus Shattock and Wolff have redefined the press and periodical study in the following terms:

The press, in all its manifestations, became during the Victorian period the context within which people lived and worked and thought, and from which they derived their sense of the outside world. $^{29}$

The periodical press is neither a mirror reflecting Victorian culture, nor a means of expressing Victorian culture, but an 'inescapable ideological and subliminal environment, a (or perhaps the) constitutive medium of a Victorian culture which is now seen as interactive. ${ }^{30}$ It is part of a matrix of meaning that encompasses the total semiotic field.

This theoretical position is the logical outcome of the process by which, through the impetus provided by social history and cultural studies, the literary source gained recognition as a viable source of evidence for historical analysis: an expression, not merely of the consciousness of the author, but of the relationship between authorial consciousness and social formation. We have now arrived at a point at which the literary source has been transformed from

27 Michael Wolff, 'Charting the Golden Stream', in Joanne Shattock and Michael Wolff (eds), op. cit., pp.26-27; Walter E. Houghton (ed.), op. cit., p.xv; John North, 'The Rationale - Why Read Victorian Periodicals?', in J. Don Vann and R. Van Arsdel (eds), op. cit., p.4.

28 Lyn Pykett, 'Reading the Periodical Press: Text and Context', Victorian Periodicals Review, XXII, 3 (Fall 1989), p.102. See, for instance, Mikhail Bahktin, The Dialogic Imagination (ed. Michael Holquist, trans. Caryl Emerson and Michael Holquist), Austin: University of Texas Press, 1981. See also Michel Foucault, The Archaelogy of Knowledge (trans. A.M. Sheridan Smith), New York: Pantheon, 1972.

29 Joanne Shattock and Michael Wolff (eds), op. cit., pp.xiv-xv.

30 Ibid. 
acceptable text (representing or reflecting an historically significant reality) into quintessential context (constituting the very essence of that reality). Interdisciplinarity - in the form of semiology, structuralism, post-Foucauldian and formalist historiography - has altered our thinking so that literature and context are viewed, in the words of Lyn Pykett, as 'indivisible elements of a signifying system, or ideological or discursive formation'. 31

A range of cultural critics from Matthew Arnold to Q.D. Leavis and beyond have constructed an opposition between art and mass culture in which the market relationship has provided the principle for a hierarchical division of the cultural field into high and low forms. Within this critical tradition, high culture, 'Literature' or (genuine) 'Art' has been theorised as a specialised discipline, pursued and defined by 'English Literature' and the academy. It has been dissociated from the realm of the common reader. 'Journalism', on the other hand, and especially 'New Journalism' (so designated by its critics) has been defined as a mass-produced cultural commodity, and writing for a mass audience (of 'consumers' rather than readers) has been viewed as an intrinsically debased cultural form, determined by market rationality, and potentially subversive in its implications for literary standards.

Within the historiography of the press itself, there has been a certain pessimism about the commercial press that was born of the repeal of the 'taxes on knowledge'(abolition of the advertisement duty in 1853, stamp duty in 1855, paper duty in 1861 and the security system in 1869). In an analysis of the commercial changes affecting the press in the half century after the repeal of the newspaper tax, Alan Lee has argued that the liberal ideal of an independent press broke down in the 1880 s and 1890 s when capitalism encroached strongly. The establishment of a free press also brought the establishment of a cheap one. The effect, according to Lee, was to create an 'intellectually more passive and morally less confident readership'. The newly commercialised press served the ends of an increasingly powerful capitalist class. Commercial motives had always underpinned the foundation and management of newspapers, but the abolition of what opponents called the 'taxes on knowledge' heralded a new phase of development in which, according to Lee, 'economic forces would gradually dominate political ones'.32 This argument has resonated through the historiography of periodical literature from the late nineteenth century to the present day.

Yet Stephen Koss has emphasised patterns of continuity in press development, in a work that is particularly relevant to Newnes's Westminster Gazette, pointing out that many organs of the so-called New Journalism were as representative of an old tradition of political journalism as of a new journalistic

31 Lyn Pykett, op. cit., p.103.

32 Alan Lee, 'The Structure, Ownership and Control of the Press, 1855-1914', in George Boyce, James Curran and Pauline Wingate (eds), Newspaper History from the Seventeenth Century to the Present Day, London: Constable, 1978, p.117. 
model..$^{33}$ Koss's argument will be taken up in Chapter 3, as will the work of Piers Brendon in The Life and Death of the Press Barons. Brendon has chronicled the rise and decline of the 'press barons' in the U.S. and Britain, suggesting that the press baron was 'a lone pioneer of outstanding journalistic ability, a man of mercury who invested his entire personality in his newspaper', and that collectively,such men transformed the landscape of journalism in the nineteenth century. They were defeated, however, by a sharp change in the economic climate and were overrun by twentieth-century 'media conglomerates' ${ }^{34}$ Although Newnes was not a 'press baron' in the strictest sense (he owned only one major newspaper), Brendon's argument is remarkably pertinent to the process of mapping Newnes's progress from editor of Tit-Bits to owner of an extensive periodical publishing empire. This book seeks to interrogate the relationship between the New Journalism and the old, and between 'serious' or 'quality' journalism and popular or commercial journalism. It offers The Strand and The Westminster Gazette, in particular, as products of the cross-pollination between the old and the new, ideology and profit, and artistic quality and journalistic innovation.

Contemporary scholars in media and cultural studies have noted the way in which producers in what they call 'the culture industries' (televisual media networks, the film industry and the magazine industry) have increasingly attempted to appeal to niche audiences through more tightly-focussed cultural products, targeting ethnic, youth, female and various other audiences. This strategy has been labelled 'narrowcasting'. It is a policy, however, that can be traced to the magazine industry of the 1890 s, an industry that was heavily influenced by the expansion of the advertising business. ${ }^{35}$ Newnes targeted a range of specialised markets at the turn of the century (thus attracting substantial advertising revenue) with a range of periodicals including The Ladies' Field and The Captain. This represented a departure from the inclusive strategies that had made Tit-Bits such a success. These two periodicals represent points of access into a range of views, anxieties and preoccupations relating to the niche audiences at which they were targeted: upper middle-class and society women and youth (primarily boys, but with some appeal to girls).

\section{Methodology}

One of the most frequently acknowledged problems of Victorian periodical research relates to the sheer mass and variety of material available to the scholar,

33 Stephen Koss, op. cit.

34 Piers Brendon, The Life and Death of the Press Barons, London: Secker and Warburg, 1982.

35 See, for instance, Michael Curtin, 'On Edge: Culture Industries in the Neo-Network Era' and David Shumway, 'Objectivity, Bias, Censorship', in Richard Ohmann (ed.), Making and Selling Culture, Hanover and London: Wesleyan University Press, 1996. 
much of it uncatalogued in bibliographical indexes. Indeed, the abundance of potential source material beckons new scholars to the field. Nineteenth-century Britain was a 'journalising society', and periodicals were an important form of entertainment for people for whom there were few alternatives to the written word as a method of mass communication. Reviewing the literary history of the nineteenth century in 1896 , George Saintsbury suggested that: 'perhaps there is no single feature ... not even the enormous multiplication of the novel, which is so distinctive and characteristic as the development in it of periodical literature'. 36 The journals established between 1824 and 1900 numbered between 125,000 and $150,000 .^{37}$ In fact, periodicals were more widely read than books. This book offers a thorough and original examination of seven periodicals established in the years from 1881 to 1899 , making them available, at least in some speculative way, to the researcher of periodical literature. It offers, in a sense, a method of organising what is a vast quantity of source material.

More specifically, the methodology of this book will consist of three approaches: an examination of the production of the periodical publication involving issues of proprietorial and editorial control, authorial and artistic input, and technical and journalistic development; an exploration of the periodical as a social object embedded in contemporary discursive and cultural practices, encompassing issues of readership, circulation, reception and cultural formation; and an interrogation of the distinctive properties of the periodical text and the 'personalities' (to use Joel Wiener's term) ${ }^{38}$ of Newnes's periodicals, involving a combination of close-reading and critical theory, and utilising the heterogeneity of the late nineteenth and early twentieth-century periodical as a means of locating it within its journalistic, cultural and commercial context.

There are various problems associated with the investigation of the input of journalists and others as it relates to the study of Victorian and Edwardian periodicals. One of these is the anonymity often exercised by journalists, editors and sub-editors in the nineteenth century. This has meant that the assumption that Newnes himself edited The Million has been based upon the fact of its similarity to Tit-Bits in editorial style and format rather than on archival evidence. Another problem is the complexity of the authority structure of the press as it became increasingly capitalised, and thus of the connection between proprietor, editor, sub-editor and publisher's reader. ${ }^{39}$ This issue has become part of the

36 George Saintsbury as cited in Joanne Shattock and Michael Woolf (eds), op. cit., p.3.

37 Joanne Shattock and Michael Woolf give an estimate of 50,000 (ibid. p.3), but more current research puts the number of Victorian periodicals at triple that figure.

38 Joel Wiener, 'Sources for the Study of Newspapers' in Laurel Brake, Aled Jones and Lionel Madden (eds), op. cit., p. 155. The Pall Mall Gazette, for instance, had been under W.T. Stead 'a demon for work, insatiable in curiosity and interest, and ceaseless in its interrogation of public opinion', according to E.T. Cook. Under John Morley, on the other hand, it had been 'grave', 'deliberate', 'weighty' and 'subdued' (p.161).

39 See Linda Marie Fritschner, 'Publisher's Readers, Publishers, and their Authors', Publishing History, 7 (1980), pp.45-100. 
conceptual framework and thematic development of this book. Newnes was more evidently the source and fount of Tit-Bits, which he established, financed and edited himself, than of The Strand, a later publication over which he exercised general editorial control but for the production of which he employed a powerful editor in Greenhough Smith, and many sub-editors, journalists, artists and compositors. He is thus central to the chapter on Tit-Bits and The Million whereas the chapter on The Strand encompasses a good deal of material on the hierarchy of constituents involved in the magazine's production. The Westminster Gazette, over which Newnes allowed his editors (E.T. Cook and then J.A. Spender) considerable editorial control and freedom from proprietorial intervention, has been depicted here as a textual site through which issues of proprietorial control were explored and mediated. And the two later Newnes publications, though still inspired by Newnes, have been shown to be the logical outcome of the process by which the responsibilities of the editor were gradually separated from those of the proprietor, as the rule of proprietors gave way to corporate management.

Comments about the reception of periodicals are limited by the absence of reliable and detailed information about circulation. From the abolition of the stamp tax on newspapers (a system which had provided some information, though not entirely reliable, about circulation) until the $1890 \mathrm{~s}$, sales figures for newspapers were not audited or certified. It is therefore difficult to obtain authoritative circulation figures. A few papers published certified figures, although these were sometimes contentious. ${ }^{40}$ Papers often made exaggerated claims about their circulation in order to attract a profitable advertising trade. Yet another complication relates to the ratio of readers to each copy in a period when papers were sometimes read aloud, and were often read by multiple readers, especially if they were 'family papers'. It is thus difficult to establish both the size and the composition of a publication's readership.

Moreover, for all the merit in recent theoretical developments, penetrating the social meaning of periodical discourse is by no means an easy task. And for all the talk of the cultural text and its effects on its audience, the periodical text is a complex form and understanding the reading process, as it relates to the periodical, a considerable challenge. The historian of the nineteenth-century press often has no archival source for actual as opposed to implied or constructed reader response (diaries, oral evidence, or unpublished reader correspondence, let alone real sales figures). Furthermore, the Victorian period was characterised by a well-tried convention of fabricating letters from readers to generate sales. There is no evidence to suggest that this technique was routinely employed by Newnes. ${ }^{41}$ Yet neither is there any record of the correspondence

40 Kennedy Jones claimed that it was common practice in the 1890 s for newspapers to overprint an edition to increase 'sales' figures and therefore advertising, despite the financial loss entailed in destroying excess stock. See Joel Wiener 'Sources for the Study of Newspapers' in Laurel Brake, Aled Jones and Lionel Madden (eds), op. cit., p.159.

41 The only reference to the use of such a practice in a Newnes publication comes from C.B. Fry, who referred to 'the intelligent questions' of Captain readers, 'real as well as 
that was rejected, and the act of reader response was itself selectively represented in the text. What is employed here is thus a rather transmission-centred approach to readership. It relies on internal textual evidence (the images of readership fostered and sustained by the text, visually, and through the various correspondence columns, competitions, circulation figures, narratives, editorials) to suggest an implied or imagined readership. (For, as Wolfgang Iser points out, the reader is not independent of textual constraints, but participates in interpretative activity within the manifold possibilities implied by the text. The text's intentions are always circumscribed by it and traceable to it. ${ }^{42}$ And it offers both anecdotal and secondary evidence for readership as far as is possible.

'Literacy', as well as literature, is dynamic and contextual. It is also a concept very much enmeshed in the history and historiography of the years 1880-1910, when successive Education Acts and the expansion of the popular press focussed attention on the spread of the reading habit. The debate over TitBits, to which Chapter 1 is a contribution, clearly demonstrates this. Literacy, as David Vincent and Gerd Baumann have argued, must be placed in its historical context, and it must be seen as a social practice within the context of other social practices, power structures, institutions and organisations in order for its diverse uses and meanings to be understood. ${ }^{43}$ The Strand, The Million and The Wide World Magazine, for instance, appealed to an audience with a considerable degree of visual literacy, fostered throughout the century by cultural texts which included ballads and broadsheets, advertising and illustrated papers such as Punch (1841) and Illustrated London News (1842). Crime fiction and crime news had been associated with a semi-literate working and lower middle-class audience in the mid-nineteenth century. But by the late nineteenth century, as A.E. Murch has pointed out, it was becoming acceptable and popular amongst a more 'respectable' readership. ${ }^{44}$ Hence middle-class periodicals such as The Strand incorporated a huge crime fiction component. The concept of literacy was subject to challenge and change, and went beyond the mere ability to read.

Yet despite being somewhat problematic and complicated, reader-response criticism does seem to offer a model of interpretation that is particularly appropriate to the periodical form, given that readers create a periodical in a way that is manifest (through buying it week after week). And the notion, derived from this critical tradition, that 'reading and writing join hands, change places,

imaginary' (my italics). See C.B. Fry, Life Worth Living: Some Phases of an Englishman, London: Eyre and Spottiswoode, 1939, p.154.

42 Wolfgang Iser, 'The Reading Process: A Phenomenological Approach' in Jane P. Tompkin (ed.), op. cit., p. 50 .

43 David Vincent and Gerd Baumann, 'Abstracts from 1993 SHARP Conference', Publishing History, 34 (1993), pp.86-87.

44 A.E. Murch, The Development of the Detective Novel, London: Peter Owen, 1968, p.9. There was a tradition of literacy associated with the self-educated reader, whose repertoire included the Bible and Pilgrim's Progress. W.T. Stead's survey of Labour MPs revealed that they had educated themselves through a common set of seminal texts. Newnes's competitions in Tit-Bits to name the 'Ten Best Books' and the like were an appeal to this tradition and an attempt to define it. 
and finally become distinguishable only as two names for the same activity' offers a valuable perspective from which to survey the effect of a large and dynamic readership upon Newnes's publications. ${ }^{45}$ It is of peculiar relevance to Tit-Bits, in which readers actually become writers in the 'Answers to Correspondents', 'Legal Tit-Bits' and 'Tit-Bits Inquiry' columns, and in which the act of editorial selection and the process of writing become very transparent and very personalised. In The Wide World Magazine too, readers were writers (in the sense of being contributors), and the magazine's readers strongly identified with the various narrators as they travelled imaginatively to all corners of the 'wide world'. In The Ladies' Field, readers' interests, as revealed in the many columns in which they participated through correspondence, constituted the magazine's field of reference: 'the ladies' field'. In The Captain and C.B. Fry's Magazine the relationship between author-editor and readers, closely allied to the relationship between the sporting or popular hero and his adoring crowd, was vital to the text's psychological effects and to its popularity. It was derived from the social fabric of a society shaped by consumerism, anxiety about youth problems, and mass spectator sport. In general, the most important methodological hint which critical theory offers in the case of this particular study concerns the importance of interrogating the way in which periodicals function as social discourse rather than as direct 'social statement'. The study of periodical literature entails a process of mediation between the discourse of certain magazines and the discursive practices of their readers.

The periodical text itself is a complex form, difficult to define. The 'text' is both the single issue, and the run of numbers of each magazine. The complex nature of the periodical text thus necessitates a mixed analytical approach. Individual issues and stories require some detailed critical analysis with attention to such devices as simile and literary allusion, to narrative technique and narratorial voice, and to the linguistic structure of reference employed. The Wide World Magazine, for example, was structured by the language of imperialism. Terms such as 'penetration', 'opening up' and 'civilising', and oppositions such as 'civilised' and 'savage', 'heathen' and 'Christian' were commonplace. This sort of approach provides access to the cultural and ideological interplay occurring between author and readers with a common ground of language, expectation and literary tradition (the traditions of literary structure and form).

A whole nun of numbers, linked by form (format, length of stories, size of pages), regular features ('Legal Tit-Bits', 'Answers to Correspondents', 'Continental Tit-Bits', 'Inquiry Column', 'Tit-Bits of General Information' in Tit-Bits; the map-contents in The Wide World Magazine) and material characteristics (green paper for The Westminster Gazette, quality of paper and photographic reproduction for The Wide World and The Ladies' Field, coloured illustrations for The Million) would seem to present a whole new set of analytical problems. This text represents a market relationship between producer and

45 Jane P. Tompkin (ed.), op. cit., p.x. 
consumer; a phenomenon related to demand, anticipation and familiarity, loyalty and time.

The fundamental characteristic of the periodical text in this second definition is the way in which it engages with its readers across time and thus involves them in the development and character of the text. Margaret Beetham has examined the formal qualities of the periodical text and explored the way in which the periodical functions as both open and closed text. ${ }^{46}$ Beetham has demonstrated that the periodical is, in one sense, 'not only characteristically selfreferring but is by definition open-ended and resistant to closure'. The serial form of the periodical implies a resistance to closure, and can thus be read as a sign of its strength as a potentially creative form for its readers, implicated in a continuing history which it both responds to and helps to define. Furthermore readers rarely read an entire periodical, nor do they read in the order of printing, or even at one sitting. They select and construct their own order. Thus the periodical is a form which openly offers readers the chance to construct their own texts (though their capacity to do so is, of course, necessarily limited by the 'text' out of which they make their own 'text') ${ }^{47}$ The interactive character of periodical literature, of which Newnes's work provides some interesting examples, thus defies conventional models of interpretation relating to literary production. Periodical literature offers openness, fluidity and the possibility of alternative meanings. Hence the reaction of readers could influence the conclusion of a serial, as in the case of the Sherlock Holmes stories in The Strand Magazine, in which Holmes was resurrected after his death at Reichenbach Falls in order to satisfy public demand for more Holmes stories. Tit-Bits has been characterised in this study by the way in which it emphasises the open, serial qualities of the form: the predominance of competitions, question/answer formats and regular features. These qualities reinforced the dynamic nature of the publication.

At the same time, the periodical form implies structure and closure inasmuch as the economics of periodical literature - the fact that success is dependent upon the maintenance of a constant, loyal readership - entails the reproduction of successful features and the linking of separate issues. Temporality endows it with a regularity of structure and a continuity of format (regular columns, page size, shape, pattern of contents), the consistency of which attracts a regular weekly or monthly readership. And the periodical form goes hand in hand with other structures in industrial society by which work and leisure have become regulated by time. ${ }^{48}$ Despite its publication in serial form, The Strand Magazine represents, in some sense, a closed text, each issue

46 Margaret Beetham, 'Open and Closed: The Periodical as Publishing Genre', Victorian Periodicals Review, XXII, 3 (Fall 1989), p.97; and Margaret Beetham, 'Towards a Theory of the Periodical as a Publishing Genre', in Laurel Brake, Aled Jones and Lionel Madden (eds), op. cit, pp.30-35.

47 Ibid., pp. $97,98$.

48 See E.P. Thompson, 'Time, Work-Discipline and Industrial Capitalism', Past and Present, 38 (1967), pp.56-97. 
remarkably complete. The self-sufficiency of the monthly number was created by the standardisation of the bound text, and by the wide use of the serial short story form pioneered by A.C. Doyle and others ( $\mathrm{a}$ form which, as Doyle pointed out, bound the reader to the magazine without excluding the reader who had missed an issue). ${ }^{49}$

Difficulties of definition arise partly out of the fact that the periodical is a mixed genre. Like the novel in Bakhtin's exposition on The Dialogic Imagination, it is 'a phenomenon multiform in style and variform in speech and voice' ${ }^{50}$ It contains a heterogeneous combination of text, pictures, maps, diagrams, rubric and captions, and is compounded of a diversity of voice and authorial contribution. The concept of authorship is problematic in the context of periodical literature because each number involves the consciousness of a number of writers, in addition to that of the editor and that of the proprietor. Thus there arises a difficulty in situating the periodical text within the locus of a particular author. In this study, editorials and correspondence columns will be closely analysed on the assumption that they represent a relatively direct and familiar form of interaction. The text's complexity will also be addressed through the examination of some particular editors, writers and illustrators in detail.

Yet the heterogeneity of the periodical text actually offers a key to engaging with the form as it developed in this period. The progress of mass culture was intimately associated with a general cultural reorientation that was, as Stephen Kern points out, essentially pluralistic and democratic. ${ }^{51}$ Periodical literature became a vehicle for maintaining and exploiting the pluralism of the market, and Newnes established a range of publications, including The Ladies' Field, The Captain and C.B. Fry's Magazine, that catered to various different reading communities. It is significant in this context that Newnes published a variety of types of periodicals, their issues separated by different intervals of time. Tit-Bits was a weekly (published on 'Thursday for Saturday') as was The Ladies' Field. The Westminster Gazette an evening daily, and The Strand, and C.B.Fry's Magazine monthlies. ${ }^{52}$ The material characteristics of each text were intimately related to the rhythms and class habits of late nineteenth-century life, work and leisure. The Westminster Gazette was printed on green paper to prevent eyestrain for readers travelling home on dimly lit suburban trains in the evening. Tit-Bits was published so that its distribution coincided with the

49 Doyle claims, in Memories and Adventures, that it was his idea to publish stories, in monthly instalments in a monthly magazine, which used the same familiar character and thus bound the reader to a particular magazine, and yet were complete in themselves. The Strand Magazine was the first to put Doyle's idea into practice. See Arthur Conan Doyle, Memories and Adventures, London: Greenhill, 1988, pp.95-96.

50 M.M. Bakhtin, op. cit., p.261.

51 Stephen Kern, The Culture of Time and Space, 1880-1918, Cambridge, Massachusetts: Harvard University Press, 1983, p.152.

52 See J. Willing, Willing's Press Guide and Advertisers' Directory and Handbook, London, 1903. 
Saturday half-holiday obtained by workers in the 1860 s, and it was substance for a week's varied reading for the commuting market. Newnes's monthlies were more complex publications, diverse and substantial enough to occupy the leisure time of a month and sustain repeated reference. The multiform and heterogeneous character of the periodical text thus represents the key to understanding its formal and commercial development, and its social meaning in the late Victorian and Edwardian periods.

\section{Biography}

This book highlights Newnes's evolution as a periodical editor, publisher and proprietor in an age in which proprietors became especially significant as popular journalism was transformed by capitalisation and the forces of commercialism. The profession of publishing only developed into a vocation in its own right in the early nineteenth century, pioneered by such enterprising and speculative venturers as John Murray and Archibald Constable. Even in those early years the issue of whether publishing (and authorship) belonged to the province of business or the realm of art was a constant pressure on publishers.

The House of Cassell expanded into periodical and serial publishing in the 1860 s and $1870 \mathrm{~s}$, founding a variety of periodicals. In 1865 Cassell were publishing three magazines, never producing more than twelve part issues per month. By 1888 , they were publishing seven magazines, never producing fewer than forty part issues per month. ${ }^{53}$ In the 1880 s, Cassell's lead in periodical publishing diminished as its proprietors failed to adapt to public taste and underestimated rival publishing enterprises. The slack was taken up by George Newnes and other innovative publishers such as Harmsworth and Pearson, who captured and retained the market through a constant stream of innovation in periodical publishing.54 They began, often with very little capital, not in bookselling or general publishing, but in periodical publishing. And they capitalised one successful periodical to establish others. Various measures paved the way for the development of the press along capitalistic lines. The Companies Act (1866) made it easier to form joint stock companies and over the next fifty years, over 4,000 newspaper companies were formed in England and Wales. ${ }^{55}$

53 See Simon Nowell-Smith, The House of Cassell, 1848-1958, London: Cassell, 1958, pp. 113-116.

54 Both Harmsworth and Pearson were given their first openings in the journalistic field by Newnes, then editor and proprietor of Tit-Bits. Arthur Pearson began his career by winning a salaried position on Newnes's paper in one of the Tit-Bits prize competitions. He went on to establish Pearson's Weekly (1890) and many other journals. The young Harmsworth, attracted by the fact that Newnes offered to pay a guinea per short column to TitBits contributors by return of post, collaborated with Max Pemberton to write an article about jerry-builders which Newnes agreed to publish in Tit-Bits (Max Pemberton, Lord Northcliffe. A Memoir, London: Hodder and Stoughton, 1922, pp.28-29) 
Before the $1880 \mathrm{~s}$, a printer, printing family or joint stock company had ownership of a single paper. By the end of the nineteenth century, according to Raymond Williams, 'whole groups of papers and periodicals were being collected or begun' around 'a new kind of speculative owner'. 56

George Newnes was such a 'speculative owner'. An idiosyncratic publisher, a Liberal MP, and a business-minded but public-spirited man, Newnes is the binding thread of this book. For the realm of Newnes's experience represents a crucial perspective on the social meaning of the periodical text as he fashioned it. If the periodical press was an interactive medium which constituted the context within which people 'lived and worked and thought', then George Newnes was an important factor in that context, and an important component of the process of interaction. And if the 'personality' of a periodical encompasses the predominant influence of the proprietor in shaping its characteristics, then Newnes was integral to the entire series of House of Newnes publications. Each section introduction will thus include an exploration of the ways in which Newnes's own experiences, preoccupations and public personality were played out in the establishment, naming and progress of his publications.

Born in 1851 at Matlock in Derbyshire, George Newnes was the son of a Congregational minister. He was educated primarily at a Congregational school in Derbyshire and then for a short time at the Shireland School in Birmingham and at the City of London School. And he spent his early working life in the wholesale business. In 1881 , using money he had raised by opening a vegetarian restaurant in Manchester, he started a weekly paper called Tit-Bits. The establishment of Tit-Bits marked the beginning of a remarkable career in editing and publishing. Politically, Newnes was firmly tied to the Liberal Party. He entered Parliament as the member for the Newmarket division of Cambridgeshire in 1885 and remained until 1895, when he lost his seat, but gained a baronetcy in recognition of his services to the party. In 1900 he re-entered Parliament as the member for Swansea and represented that constituency until 1910. He was also a JP at Lynton, in North Devon, where he built a country house in 1893.

Newnes's formative years are illuminating in relation to his later success as an editor-proprietor. Being reared in a Congregationalist religious environment meant that Newnes was also exposed to Liberal political principles very early in life. Congregationalism and Liberalism were closely associated, and Newnes's father was an ardent Liberal. Silcoates School, which Newnes attended from the age of 6 , was a school for the sons of Congregational ministers and missionaries. In the register of the parents, distant places such as Chinsura, Madras and Mauritius were represented. Many of these places were later to feature in The Wide World Magazine. At Silcoates, the spirit of broad liberalism prevailed, and the school's popular principal, Dr J. Bewglass, was a

55 Other measures included the abolition of the advertisement duty in 1853, stamp duty in 1855, and paper duty in 1861. See George Boyce, James Curran and Pauline Wingate (eds), op. cit., London: Constable, 1978, pp.68, 151.

56 Raymond Williams, The Long Revolution, pp.200-229. 
staunch Liberal. When there was an election at Wakefield, masters and boys all joined in the excitement and enthusiastically supported the Liberal candidate. It is not, therefore, surprising to find Newnes entering parliament as a Liberal MP in 1885 , becoming a member of the National Liberal Club (founded in 1882, and opening its first premises in June 1887), and establishing The Westminster Gazette, a Liberal evening newspaper, in 1893. Assessing the legacy of his time at Silcoates, W.T. Stead, who was Newnes's contemporary at the school, said that he learnt three important things: 'Christianity, cricket and democracy' ${ }^{57}$ Many Newnes publications may be seen as products of that legacy: the Sunday Strand as a medium of Christianity; C.B. Fry's Magazine and The Captain as purveyors of the cricketing ethos; and Tit-Bits, The Million and The Westminster Gazette as attempts to publicise and exploit democratic principles.

When George Newnes was a boy in the late 1850 s and 1860 s, he was an avid reader of Fenimore Cooper stories and had visions of embracing a life of heroic adventure. He later provided generations of boys with such stories in The Wide World Magazine and The Captain. As a schoolboy, he soon became 'profoundly impressed with the importance of religion' (not surprising, since his father was a Congregational minister). He held weekly prayer meetings at his school and aspired to become a preacher, an aspiration of which his parents strongly approved. Whilst he did not follow such a career path, he did later provide the religious with a popular medium of communication in the Sunday Strand (1900). The adolescent Newnes subsequently became, as he put it, 'stagestruck', and went to the theatre four nights a week with a friend in pursuit of the kind of familiarity with the stage that he saw as a necessary grounding for a theatrical career.

We knew better than many of the critics the plot of every play that came out about that time, and the characteristics of every actor and actress upon the London stage.

It is significant, in this context, that The Strand's popular 'Portraits of Celebrities' series featured many celebrities of the London stage.

In 1899 , Newnes wrote, for a series entitled 'What I Wanted to $\mathrm{Be}$ ' in The Captain:

My next ambition was destined to take practical shape. I became a greedy devourer of all kinds of periodical publications. Besides my own purchases I used to pay my Newsagent a shilling to let me spend a couple of hours in his shop, turning over the pages of the various publications, and, as he took most of those issued, it was very interesting. There I examined them, criticised them, and tried to improve upon them.

57 W.T. Stead as cited in Reginald Pound, op. cit., p. 14.

58 The Captain, 1 (August 1899), p.493. 
In fact, at that time my thoughts were largely upon journals and magazines, and I suppose they have been largely upon them ever since.

Newnes went on to establish dozens of successful periodicals, improving upon old formats and developing new ones.

As an employer, George Newnes acquired a reputation for benevolence and collaboration that matched the editorial image he cultivated in Tit-Bits, The Million and The Strand. He was regarded with respect and affection as a just and benevolent leader. A volume presented to him by his employees in 1900 to celebrate the thousandth issue of Tit-Bits, and addressed to 'Sir George Newnes, Bart, MP', resembled a petition of thanks to the lord of the manor:

... we, who have been associated with you so intimately at the offices of George Newnes Ltd, would ask you to accept this as a personal token of the pleasant relations, indeed, one might almost say respectful affection, which has always existed between employer and employed. This is a unanimous feeling. There are those who have been with you for years, there are others who have been with you for a little while. But this gift is one which represents the esteem and regard of all. We sincerely appreciate your kindness and thoughtfulness in all matters affecting the welfare of your employees here. As the head of this great firm you have a well-deserved reputation for energy and business enterprise. In all dealings with us you have won our sincere regard for your justice and generosity.

Permit us to wish you and yours every happiness in life.

Newnes acted out his seigneurial image. 'Quite unconsciously', observed Friederichs, 'the founder and first proprietor of The Westminster Gazette had a lordly way about him.' When E.T. Cook suggested that the former editorial staff of the $P M G$ would be willing to transfer their services to the new publication, Newnes said only, 'Well, bring them all over.' 60 Busts of Newnes were distributed about the country, at the places to which he made substantial benefactions (Putney, Lynton and Matlock), in a manner which reinforced his local connections as well as his national reputation (see Figure l).

Newnes's editorial image also paralleled his local reputation in Lynton, North Devon, where he built a country residence. And his journalistic method paralleled his devotion to championing the interests and winning the approval of the local population. 'Never in Lynton and Lynmouth's long history', John Travis has recently remarked in a Churchillian manner, 'has so much been owed to one man':

\footnotetext{
59 Ibid.

60 Hulda Friederichs, op. cit., p.224.
} 
From the moment George Newnes first set foot in the town, he played a leading part in its development. He spent freely, exerted enormous influence and brought about major changes. ${ }^{61}$

On Hollerday Hill, just above the town of Lynton, Newnes built a beautiful country mansion called Hollerday House. It was built by local workmen and completed in 1893. With views of sea, rock, moor and woodland, established gardens, woods, tennis courts, bowling greens and croquet lawns, it was the kind of residence that might have appeared in Country Life, founded jointly by Newnes and the firm of Hudson and Kearns in 1897. To Hollerday House, Newnes and his family and friends adjourned each summer to escape the noise and crowds of London. It was a tangible form of the kind of escapism that he provided in Country Life and The Wide World Magazine. In a gesture that was typical of this instinctive host and paternalist, Newnes opened Hollerday Hill to the general public, stipulating only that visitors should not pick the ferns and other rare plants he had planted. He paid for Warren Field, in the Valley of the Rocks, to be levelled for a cricket ground in 1891 (the year that the The Strand was established), and arranged to have a cricket pavilion erected. In May 1894, he performed the opening ceremony at the new golf course on Martinhoe Common, which he had helped to pay for. He also funded a new bowling green, on a site immediately below Hollerday House, in 1904 (the year that C.B. Fry's Magazine was established).

Newnes found that Lynton lacked the kind of public building requisite for a fashionable watering place and that the inhabitants were unable to raise the funds necessary to build one. So he bought a plot of land on Lee Road and offered to build an impressive town hall as a gift to the community. The foundation stones were laid by Lady Newnes and another prominent local woman, Mrs Jeune, on 11 May, 1898, the same year in which two new Newnes publications were established: The Wide World Magazine and The Ladies' Field. The town hall took two years and cost $£ 20,000$ to build.62 It was opened in the same year that the Sunday Strand was established. On 15 August, 1900, Sir George Newnes performed the opening ceremony (see Figure 2). He formally handed over the building to the town, expressing the hope that it would be 'a source of instruction and recreative pleasure, not only to the present inhabitants, but to future generations', ${ }^{63}$ Such rhetoric echoed his publishing manifesto: that his journals provided 'wholesome instruction and entertainment'. The building's cornerstone bore the words 'Erected by Sir George Newnes baronet, JP and presented by him to Lynton and Lynmouth For Ever'. And in 1902, a bust of Newnes was placed at the site 'by the inhabitants of Lynton', as the inscription read, 'in recognition of the many benefits he has

61 John Travis, op. cit., p.96.

62 The local building firm of Jones Bros. obtained the contract.

63 It now houses the public library, council rooms and cinema. 
conferred on them including the gift of this hall'. It was unveiled by Arthur Conan Doyle. ${ }^{64}$ The name of George Newnes was thus as familiar to the people of Lynton as it was to the periodical-reading public. T.H.S. Escott observed that the donation of Lynton Town Hall and Putney Library (opened in 1899) were 'two specimens of conduct which made George Newnes the most widely popular as well as prosperous newspaper runner of the new era'. ${ }^{65}$ They were, of course, good publicity as well as good deeds.

Approached by local Congregationalists in 1903 for a donation towards the cost of a new church, Newnes offered to pay for a larger site and for the construction of a spacious church, as a memorial to his father and an expression of his commitment to Congregationalism and the local community. The new church was opened in 1904. The Reverend R.J. Campbell, a famous London preacher, conducted the opening services. Newnes was later to make him a present of a new car. This scenario of organising the appearance of a celebrity and dispensing a lavish gift resembled one of Newnes's journalistic schemes. It serves to underline the connection between Newnes's public personas, editorial and seigneurial, and adds a new dimension to Stead's representation of the editor as 'the uncrowned king of an educated democracy'.

The clarity of this connection between the social and journalistic spheres is only enhanced by an understanding of the pivotal social role that Newnes and his family played at Lynton. 'George Newnes was a national figure who brought prestige and excitement to a small provincial resort', observes John Travis. ${ }^{66}$ Many famous people, including Conan Doyle, gravitated to Lynton to be entertained by Newnes, just as authors and illustrators gravitated to his publications. Every summer, the arrival of the Newnes family was greeted with great rejoicing. Flags were flown, and a canon fired. On major occasions organised by Newnes too, such as the opening of the Lynton-Barnstaple railway, houses were decked with flowers and bunting, floral arches were suspended across the streets, bands played, and the people formed into long processions. At the coming of age of Frank Newnes, in September 1897 (the year that Country Life was founded), the Royal North Devon Hussars Band led a long procession through the town and up to Hollerday House, where Frank was presented with a silver salver from the inhabitants. The procession then returned to a field in town where upwards of 2,000 people were treated to a feast of turkey, goose, duck, beef and ham. In the evening, Hollerday Hill was illuminated with 14,000 electric lights. And the celebrations were rounded off with a fantastic display of fireworks and the firing of a huge bonfire. It was a day that remained long in local memories and an extravagant feat of publicity worthy of the great publisher. Newnes was much moved by the affection shown by the local people.

64 According to the Lyn Journal, Sir George said on thanking them that it was so lifelike that, when leaving the studio, he absentmindedly put his hat on the bust and walked out bare-headed. See Frederick Juniper, The Lyn Joumal (handwritten), 1956, Lynton Library.

65 T.H.S. Escott, op. cit., p.258.

66 John Travis, op. cit., p. 104. 
It was hardly surprising that he offered to build the town hall later that month. ${ }^{67}$ As a Liberal MP, Newnes had organised many similar occasions in an effort to rally support for the Liberal party. In June 1895 , for instance, he had organised a demonstration in his seat in Cambridgeshire on Whitsuntide Feast Day, providing tea for 1,200 people, and organising for John Burns to give the public address. ${ }^{68}$

Newnes was very much aware of the transformations wrought by the communications revolution, and was a great devotee of new technologies (not only of printing technology, but of the automobile, the telephone, and of electric light). This aspect of Newnes, characteristic of his generation, was represented in The Wide World Magazine. When he made his first visit to Lynton to stay with Thomas Hewitt in September 1887, he had been shocked at the sight of the horses toiling up the steep hill from Lynmouth to Lynton. He immediately entered upon a scheme for a cliff railway in partnership with Hewitt and Bob Jones, the local engineer, putting up most of the capital himself. 'This was the way George worked', according to Travis:

He saw an opportunity and took it. Schemes which met a public need and at the same time made him a profit appealed to him. He was quick to realise that the novelty of a cliff railway would bring in many visitors and might restore local prosperity, while at the same time providing him with a good return on his investment. ${ }^{69}$

There was thus a significant parallel between Newnes's publishing ventures, in which he combined business and benevolence with great success, and his other investment schemes. An Act of Parliament to build the Cliff Railway was obtained, at considerable expense, in 1888, and the work was completed by 1890. George Newnes presided at the opening ceremony in April 1890. Newnes was also chairman of the company which devised a scheme to build a narrowgauge railway between Lynton and Barnstaple, and was the leading financier of the railway. The cutting of the first sod was seen as an occasion for much celebration and Newnes was honoured by the local population as the father of the scheme, again playing a major part in the festivities (see Figure 3). The railway was opened in 1898, the same year that The Wide World Magazine was established.

In public life, Newnes was thus a figure of benevolent paternalism, dispensing great gifts to an admiring public just as, in the guise of the New Journalist and through the medium of the popular periodical, he promoted various philanthropic causes and bestowed many lavish prizes. ${ }^{70} \mathrm{His}$ acts of

67 Ibid.

68 Newnes to John Burns, 30 May, 1895, Burns Papers BL, Add. MS. 46295. ff.104b.

69 John Travis, op. cit., p.114.

70 The technique of employing the widely-circulating organs of New Journalism as agencies of publicity and support for philanthropy and social reform was particularly characteristic of the period. Note, for instance, the journalistic reform campaigns waged by 
charity, public and private, are too many to enumerate. Among the causes he supported were the Salvation Army and the Boys' Empire League. One West Country paper published an article, entitled 'The Story of Sergeorge the Giver' and written in the style of the monastic chroniclers, which depicted Newnes as a medieval Christian knight. It described his many gifts to Lynton, and the esteem in which he was held there. The community's reception of the cliff railway, for instance, was rendered in biblical language: 'And the people who were glad spake unto him and thanked him, and they stood before him and blessed his name.' 71 George Newnes, otherwise known as 'Sergeorge the Giver' in the West Country and 'Gentleman George' in his electorate of Swansea, played the part of the editor-squire instinctively and in multifarious settings.

Newnes was a self-made man: the very embodiment of the liberal, selfhelp ideology which he so strongly advocated. There was a distinctly educational, self-improving flavour about the popular knowledge volumes which he began producing at the turn of the century. And with his 'Household Series', his 'Pocket Classics', and his 'Red Cloth 6d. Library', Newnes offered the lower middle and upper working-class reader, and the female or juvenile reader, the status of the self-educated specialist. ${ }^{72}$ His journalism was also informed by an awareness of the urge towards self-improvement which pervaded midVictorian morality and contemporary business instincts. Upbringing and temperament rendered Newnes open to the self-help gospel proclaimed by Samuel Smiles in his popular book of 1859 , Self Help. He was a methodical man with a deep sense of personal integrity and a breadth of knowledge in the areas of law and business. ${ }^{73}$ His Sunday Strand, begun in 1900, was overtly religious in tone, but his other publications tended to be imbued with general moral ideas rather than being directly concerned with piety. Newnes's Congregational associations, however, were a bar to his developing the Weekly Dispatch along the sensational lines of its chief competitors, Lloyd's Weekly Sunday News and News of the World, and after failing to make a success of this paper, he sold it to the Harmsworths.

The fortunes of the House of Newnes closely mirror the biographical bell curve inscribed by George Newnes, lending an intrinsic logic and symmetry to the chronological scope of this study. Beginning as a commercial traveller with a

W.T. Stead through the Pall Mall Gazette, and the philanthropic schemes administered by Cyril Arthur Pearson through Pearson's Weekly.

71 Hulda Fricderichs, op. cit., pp.195-197.

72 Newnes published sixpenny volumes of the works of contemporary novelists such as Rider Haggard, Hall Caine, A.E.W. Mason, W.W. Jacobs, Stanley Weyman and Edgar Wallace. The Household Series included practical manuals on a range of subjects such as dogcare, home medicine, household management, gardening, cookery, needlework, and even a pronunciation dictionary. The idcology of professionalism and the rhetoric of expertise were thus extended to encompass novel reading, household work, popular music, patterns of speech and so on.

73 Newnes's concern with legal issues relating to publishing is also apparent in a number of letters written to G.H. Hoyle of the Devon and Exeter Daily Gazette in November 1887, and held by the Secretary of the Lynmouth and Lynton Lift Company. 
clerk's salary and limited career prospects, Newnes entered the publishing profession with a modest publication that appealed essentially to the lower middle-class reading public. The next ten years constituted a building stage, as Tit-Bits gathered momentum, and its editor-proprietor began to rise in social and financial status. Newnes built a magnificent house at Putney Heath and, in the 1885 General Election, won the Tory stronghold of Newmarket for the Liberals.

The next decade constituted a sort of 'Golden Age' for Newnes. In 1891, Newnes's publishing business was flourishing, and was floated as a company. The annual dividend of 10 per cent which he guaranteed for the next five years was consistently earned. This was a period of journalistic experiment and success, confidence, wealth and generosity for George Newnes. He established a succession of new, innovative and profitable publications, and the fruits of his success were amply distributed at Lynton, Matlock (his birthplace) and Putney (his London address) into divers other business projects, and amongst family, friends, employees and philanthropic organisations. 'George Newnes was building up a publishing empire', observes John Travis. 'Soon he branched into other forms of business. Everything he touched seemed to turn to gold .... George Newnes had become a celebrity. ${ }^{74}$ 'The Million' was undoubtedly a name that bespoke Newnes's confidence in his financial prospects.

Yet in the last few years of his life, Newnes's ability to make money seemed to desert him. A number of unsuccessful business ventures and investments led to his losing much of the fortune he had accrued. A venture in oil-shale mining in New South Wales cost him $£ 240,000$. His temporary partnership with Lord Northcliffe's younger brother, Leicester Harmsworth, promoting the Darracq motor car to the British market, met with some success. But he forfeited most of his gains with a heavy investment in Peruvian rubber. A number of shaky speculative schemes in London for which he provided capital a hammock-sprung motor-car seat, the 'Ever-clean' collar for men, and a device to equip motor-car wheels with springs in place of pneumatic tyres - were also failures. Even some of his schemes for new ventures in the book publishing field were doomed to failure. 'Thin Paper Classics' and 'The Art Library', both beautifully produced series, were nevertheless totally uneconomical at their selling price, and caused the company heavy losses. ${ }^{75}$ The effect of these ventures was to decrease the value of the Newnes shares, and the dividend rate reached its lowest at 2.5 per cent. George Newnes personally contributed an

74 John Travis, op. cit., p.98. In these years, Newnes bought Weldons Ltd, and secured the purchase option for the company of the French manufacturer of motor-cars, Mr A. Darracq, immediately raising the necessary subscriptions for the purchase of the company which flourished afterwards, providing considerable returns.

75 A book department was established in 1895, and various projects in book publishing, such as Newnes's Penny Library of Famous Books (1895), Newnes's Pocket Classics (1903), Newnes's Devotional Series (1906), Newnes's Household Series (1910), and Newnes's Playtime Series (1910), followed. 